\title{
DERGISI
}

ANKARA UNIVERSITY JOURNAL

SOCIAL SCIENCES

10.33537/sobild.2020.11.2.19

\section{Makale Bilgisi}

Gönderildiği tarih: Kabul edildiği tarih: Yayinlanma tarihi:

29.11.2019 06.05 .2020 30.06.2020

\section{Article Info}

Date submitted: Date accepted: Date published:
29.11.2019 06.05 .2020 30.06.2020

\section{EDREMİT DENIZ SAVAŞI (1334)}

BATTLE OF ADRAMYTTION (1334)

\section{Umut BAYAR}

Ankara Üniversitesi, Sosyal Bilimler Enstitüsü, Tarih (Ortaçağ Tarihi) Anabilim Dalı Doktora Öğrencisi, umutbayar1853@gmail.com

\section{Sait Emre ÇİFTÇi}

Ankara Üniversitesi, Sosyal Bilimler Enstitüsü, Tarih (Ortaçağ Tarihi) Anabilim Dalı Doktora Öğrencisi, saitemreciftci@gmail.com

\section{Anahtar sözcükler}

Karesi Beyliği; VI. Philippe; XXII. Iohannes; Rodos; Yahşi Bey; Edremit Körfezi

\section{Keywords}

Beylik of Karasi; Philip VI; John XXII; Rhodes; Yahsi Bey; the Gulf of Adramyttion

\section{$\ddot{0} \mathbf{z}$}

Türk gazilerinin XIV. yüzyılın ilk çeyreğinde yaptıklar sürekli akınlar Yakindoğu'da üsleri bulunan Hristiyan devletlerin tepkisini çekmiştir. Bu akınların kaynağı Batı Anadolu'da yer alan denizci Türk beylikleriydi. Onlardan birisi olan Karesi Beyliği, Doğu Roma imparatorluğu çevresinde ve Kuzey Ege'de önemli bir tehdit haline gelmiştir. 1320'lerden itibaren Türk denizcileriyle savaşmakta olan Venediklilerin Avrupa'da Türkler aleyhinde propagandalar da böyle bir seferin oluşmasina katkıda bulunmuştur. Buna rağmen Fransa kralı VI. Philippe ve Papa XXII. Iohannes'in esas arzular Kudüs'ün Hristiyanlar tarafindan geri alınmasıdır. Venediklerin Türk aleyhtarn söylemleri ve Türk gazilerinin akınlarn Ege Denizi'nde bir Haçlı ligi oluşturulması fikrini kuvvetlendirdi. 1331'den itibaren başlayan ilk müzakereler 1332 yılında Rodos'ta yapılan görüşmeyle sonuçlanmiş, çeşitti sebeplerle ittifakın tam oluşmas 1334'e kadar sürmüştür. Birleşik Haçlı donanması Karesi Beyliği'nin Bergama kolunun lideri Yahşi Bey'i boyunduruk altina almak için harekete geçip Edremit Körfezi'ne gelmiş, bunun sonucunda 1334 tarihli Edremit Deniz Savaşı yaşanmıştır. Savaşı Haçlı ordusu kazanmış, Karesi donanması ağır bir hezimete uğramıştır. Edremit Deniz Savaşı galibiyeti 1291'de Akka'nın düşmesinin ardindan Haçlilarin ilk önemli başarısı olmuş ve daha sonraki Haçlı liglerinin kurulmasını temellendirmiştir.

\section{Abstract}

In the first quarter of 14th century Turkish ghazis' incursions caused the reaction of Christian states because of their trading points in Near East. The main source of these incursions was Turkish maritime principalities. Beylik of Karasi or Karasids, which was one of these principalities, became a crucial menace in Northern Aegean Sea and around the Eastern Roman Empire. Venetians were in conflict with Turks from the 1320s, their propagandas contributed formation of such expedition as well. Philip VI the King of France and the pope John XXII had different priority compared to Venetians. They aim to recover Jerusalem and desired the domination of Christendom once again in Holy Land. Venetian propagandas and Turkish raids strengthened the idea of Naval League in Aegean Sea. First negotiations started from 1331 and Naval League was established in Rhodes (1332). However the formation of league due to external reasons lasted by 1334. Galleys of Naval League arrived at the Gulf of Adramyttion in order to subdue Yahsi Bey of Karasi who was the leader in Bergama section of beylik. They won this battle (the Battle of Adramyttion) and Karasid navy was completely defeated. The Battle of Adramyttion was the first success of Crusades after the fall of Acre in 1291 and it became an example for next naval leagues 


\section{GİRIŞ}

Karesi Beyliği Batı Anadolu'da Çanakkale ve Balıkesir illerini kapsayan, İzmir'in kuzey sınırlarını da içine alan Mysia (Misya) bölgesinde kurulmuştur. En önemli denizci Türk beyliklerinden birisi olan Karesi Beyliği'nin soyunun XI. yüzyılın ikinci yarısında Orta Anadolu'da devlet kurmuş Melik Danişmend Gazi'ye dayandığı iddia edilmektedir. Buna göre Anadolu Selçuklu Devleti'nin Danişmendlilere son vermesinden sonra Danişmend bakiyeleri Selçuklu hizmetine katılıp Bizans sınırındaki uçlarda kumandanlıklara getirilmişlerdir. ${ }^{1}$ İlhanlı hükümdarı Gazan Han'ın 1302 yılında yaptığı Anadolu taksimatında da Kayseri-Çorum ve Kastamonu hattının batısında Çanakkale-Edremit sahillerine kadar uzanan yerler "Danişmendiye Vilayeti" diye adlandırılmıştı. Germiyan kuvvetlerinin Batı Anadolu'ya akınlar yaptıkları dönemde onlara tabi olan, Pachymeres ve Nikeforos Gregoras'ın "Kalambis" diye belirttikleri, Kalem Bey ve oğlu Karesi Bey pozisyonlarını kuvvetlendirerek yanlarındaki Germiyan unsurlarıyla Misya'ya gelip burada faaliyet göstermissler, tahminen 1296-7 yıllarında² Misya'yı ele geçirmeye başlamışlar ve Karesi Beyliği'ni kurmuşlardı. (Uzunçarşıll, 2003, s. 9697; Öden, 1999, s. 8) Aynı dönemde Bitinya bölgesinde Osman Gazi'nin askeri faaliyetlerde bulunmas1, Frigya bölgesinde Germiyanoğlu3 ${ }^{3}$ I. Yakub'un ileri harekâtı Bat1 Anadolu'nun artık Türkler tarafindan ele geçirilmeye başlandığının göstergesiydi.

Doğu Roma savunma sisteminin bu bölgede çökmesi sonucu Karesi Bey güneyde Edremit Körfezi'ne, kuzeyde Erdek Yarımadası'na ve batıda Biga'ya kadar olan coğrafyada akınlar yapmıştır. Doğu Roma imparatoru II. Andronikos Palaiologos onlara karş1 10-16 bin arası bir Alan kuvvetini oğlu IX. Mikhael Palaiologos komutasında Batı Anadolu'ya göndermiști. Mikhael bu orduyla 1302 yılında Türk baskısını hafifletmek amaciyla kuzey-güney istikametinden hareket ederek Karesi topraklarından geçti. (Öden, 1999, s. 21) Karesi kuvvetlerinin Misya'dan geçen bu orduyu vur kaç taktiğiyle yıpratmasından sonra Alan destekli Doğu Roma ordusunun ilerleyişi Germiyanlıların saldırı noktası olan Gediz nehri havzasina kadar devam etmiştir. İlerledikçe Doğu Roma ordusunun şartları ağırlaşmış, II. Andronikos'un tecrübesizliği bir yana birliklerin çoğunu oluşturan Alanlar ailelerinden uzak kaldıkları için savaşma isteklerini yitirmişlerdi. Bu birliklerin karşısındaki Türk birlikleri ise yüksek savaş deneyimine sahip olan moral seviyesi ve mobilizasyonu yüksek, yurt bulmak için savaşma arzuna sahip birimlerden müteşekkildi. (Öden, 1999, s. 21) Doğu Roma ordusu bu şartlara rağmen Manisa'ya ulaşmay1 başarsa da Alanların desteğini çekmesiyle tamamen dağılmaya yüz tuttu. Mikhael onların dağılmasını engellemek için babası II. Andronikos'tan ekstra ücret

${ }^{1}$ Sultan II. Kılıçarslan'ın 1174'te Sivas'1 ve 1178'de Malatya'yı ele geçirmesinden sonra Danişmendliler dağılmışlar, bir kısmı Selçukluların idaresi altına girmişti. Bunlar arasında Nizameddin Yağıbasan'ın oğulları Muzaffereddin Mahmud, Zahireddin İli ve Bedreddin Yusuf bulunuyordu. Selçuklular sultan II. Kılıç Arslan döneminde onları batı sınırlarına naklederek uç beyleri yapmışlardır: Bkz. Öden, 1999, s. 7

${ }^{2}$ Karesi Beyliği'nin kuruluş y1lı olarak İsmail Hami Danişmend 1300 yılını, Uzunçarşı1ı 1296-7 yıllarını ve Erdoğan Merçil 1297 yılını vermişlerdir: Bkz. Öden, 1999, s. 19 talep etmişti. Fakat bu teminat onların sadakatini uzun süreli hale getirmedi. Kuvvetlerin dağılmasından ötürü IX. Mikhael de birlikleriyle Bergama'ya çekildi. Onun bu geri çekilişi Kyzikos'a (Erdek) ve Pegai'ye (Biga) kadar devam etmiştir. Doğu Roma'nın geri çekilmesi Türk saldırılarının devamını getirdi. (Öden, 1999, s. 21) KaleKent kimliğine sahip olmayan bölgelerde etkili olan Türk akıncıları Misya'da daha efektif hale geldiler. Karesi Bey komutasında Karesililer Akira'dan Edremit Körfezi'ne kadar olan yerlerde akınlar yaptılar. (Bayar, 2019, s. 38)

Alanlardan sonra Doğu Roma imparatorluğu kırsallardaki hâkimiyeti tamamen kaybetmiş, sadece Kale-Kent ve Liman kentlerinde hüküm sürebilmiştir. Batı Anadolu'ya devam eden Türk akınları Doğu Roma topraklarının boşalmasına, yerlilerin savunmasız gördüğü yerlerden kaçmasına neden olmuştur. II. Andronikos dönemi askeri yapısının çökmesi de Türk akınlarını kolaylaştıran etmenlerden birisidir. 1281'deki Venedik-Bizans Savaşı'ndan sonra 1285'te donanmayı lağveden Andronikos, eski Pronoia sisteminin de işlevsiz hale gelmesi nedeniyle askeri birlikler üretememiş ve sırtını paralı askerlere bağlamıştır. (Ostrogorsky, 2015, s. 447; Raffaele ve D'Amato, 2016, s. 10; Nicol, 2000, s. 202-203; İnalc1k, 1993, s. 311) Bu nedenle Alan ücretli askerlerinden sonra yardımcı birlikler olarak, 1302'de Vesper Savaşı'nın birinci kısmının Caltabellotta Barışı'yla tamamlanması üzerine işsiz kalan, Aragon Tacına bağlı Trinacria Krallığı'ndan Katalanlar çağırılmışlardı. Katalanlar liderleri Roger de Flor'a çok sadık olan bir gruptu. Doğu Roma yönetimi de onları kendisine bağlamak istediği için Roger de Flor ile yakınlık kurmuştu. İmparator Andronikos Katalanların dört aylık parasını peşin ödemiş, yeğeni Maria Asen’i Roger de Flor ile evlendirerek akrabalık bağ olussturmuştur. Ayrıca Roger de Flor'a "Megas Doux" adı verilen amiral rütbesi verilmiştir. Katalanlar gemilerle İstanbul'a geldikten sonra 1304'te 6 bin kişilik bir kuvvetle Kyzikos'a (Erdek) çıkmışlard1. (Öden, 1999, s. 22; Miller, 1908, s. 213; Vasiliev, 2016, s. 676; Ostrogorsky, 2015, s. 444-455) Onların gelmesi Bat1 Anadolu'daki gelişmelerin seyrini değiştirdi. Karesi ilerleyişi durduran Katalanlar Güney Marmara'dan Philadelphia'ya (Alaşehir) kadar olan bölgede kısa süreli başarılar elde ettiler. Aynı zamanda kuşatma altındaki Alaşehir'de Germiyanoğlu I. Yakup'u mağlup etmişler, burayı Doğu Roma İmparatorluğu'na yeniden kazandırmışlardır. (Uzunçarşı1ı, 2003, s. 42) Doğu Roma'nın Batı Anadolu yerleşimleri, sahil kentleri ve kale kentler onların bu başarılarıla Türk hücumlarından bir nebze kurtulmuşlardı. Buna rağmen Katalanların disiplinsiz davranışları ve kendilerini üstün görmeleri Doğu Romalıları bezdirmiş, Bulgar saldırılarına karşı Trakya'da kullanılmak üzere Gelibolu'ya çağırılmışlardır. Roger de Flor da kış mevsimi geldiğinde Çanakkale'deki Lampsakos'a

3 Karesi, Saruhan, Aydın ve İnançoğulları Beyliklerinin kurucuları Germiyan Beyliği'ne bağımlı kimselerdi. Fuad Köprülü de bu kurucuların Germiyan ümerasından gelen kişiler olduklarını söylemiştir. El-Ömeri'nin Mesâlikü'l-ebsâr adlı eserinde de Germiyan beyinin bütün Türk beylerinin hâkimi olduğu ve Doğu Roma imparatorundan her yıl yüz bin altın haraç aldığı geçmektedir: Bkz. 20 
(Lâpseki) giderek Gelibolu'da kışı geçirmiştir. (Nicol, 2016, s. 161-162; Ostrogorsky, 2015, s. 455; Vasiliev, 2016, s. 678; Öden, 1999, s. 23) Katalan gücüne son vermek isteyen Doğu Roma yönetimi paralı askerlerle karş1 karşıya gelmeyi göze aldılar. Nisan 1305'te imparator II. Andronikos'un oğlu IX. Mikhael Edirne Sarayı'nda Roger de Flor'u ortadan kaldırarak sorunu çözdüğünü sanmiştır. Roger de Flor'un ortadan kaldırılmasına hiddetlenen Katalanlar Doğu Trakya'ya çağrılmalarından sonra civardaki yerleri yağmalamışlar ve Doğu Roma savunma sistemi Türklerin Batı Anadolu'ya hücumlarının ardından yeniden çökmüştür. ${ }^{4}$ (Katalanlar Trakya'dan güneye Yunanistan'daki Atina'ya kadar inerek Atina Dukalığı'nın yönetimini ele geçirecekler ve bununla birlikte Neopatras Dukalığı'nı kuracaklardır.) Anadolu'da sonuç olarak Katalanların faaliyetleri Batı Anadolu'da son geniş çaplı Doğu Roma direnişini de çökertmiştir. (Bayar, 2019, s. 42) Bu durumdan istifade etmek isteyen Karesililer 1305'te Ege sahillerine yöneldikten sonra Assos, Bergama ve Dikili kentlerine yoğun baskı oluşturdular. Assos ve Bergama gibi kalekentler uzun bir süre Karesi kuşatmasına maruz kaldılar. Karesi kuvvetleri 1328 tarihinden önce Assos, Bergama ve Dikili'yi ele geçirmeyi başarmışlardır. (Bayar, 2019, s. 42) 14. yüzyılın başlarında Foça'ya hâkim olan Cenovalılar tarafından Türklere karş1 savunulan Edremit ise bu fetihlerden daha sonraki bir tarihte, 1328'den sonra alınmıştır. (Turgut, 2016, s. 181; Öden, 1999, s. 24)

Karesi Bey ve oğulları Biga Yarımadası'nda Türk nüfusu iskân ederek Doğu Trakya'yı tehdit etmeye başlamışlardı. Komşuları olan Saruhan, Germiyan ve Osmanlı Beylikleri ile çatışmaya girmekten kaçınan Karesililer Çanakkale tarafına yoğunlaşmışlardır. (Bayar, 2019, s. 43) Ücretli askerlerden beklediği fayday1 elde edemeyen Doğu Roma imparatorluğu Bat1 Anadolu'da bu gibi Türk saldırılardan dolayı 1320'lerde Avrupa'ya yanassmak zorunda kald1. (Laiou, 1970, s. 379; İnalcık, 1993, s. 314) İktidarının genelinde batıdan izole bir siyaset izleyen II. Andronikos Palaiologos yukarıdaki nedenlerden dolayı politikasını değiştirip babası VIII. Mikhael gibi Batı kilisesiyle birleşme "union" arayışına girmiş ve Papa XXII. Iohannes'e elçiler gönderip konu hakkında fikirler almıştır. Cenovalı bir soylu olan Simone D’Oria Doğu Roma adına Fransa kralı IV. Charles'a gidip barış teklifi ve Doğu ile Batı kiliselerinin birleşmesi sözünü taşımıştı. (Laiou, 1970, s. 381-383) Çok geçmeden II. Andronikos'un siyasetinden rahatsız muhalif grupların sesi olan III. Andronikos dedesi II. Andronikos'u tahttan indirip yeni imparator olmuştur. (Laiou, 1970, s. 381-383) III. Andronikos (1328-1341) Karesi Bey'in oğlu Demirhan Bey ile Sizik şehrine gelindiğinde Çanakkale kıyı kentlerine saldırı yapılmayacağına dair bir anlaşma yapmiştır. (Zachariadou, 1983, s. 16; Uzunçarş111, 2003, s. 98) Andronikos 1328 yılında Kyzikos'a gelmiş, burada korunan Tanrı'nın anası ikonunun önünde diz

4 1307'de ortak imparator olan IX. Mikhael Alanlar ve Turkopollerden müteşekkil ordusuyla Katalanlara meydan okumustur. Buna rağmen 10 Temmuz 1307 tarihli Apros Savaşı'nda Turkopoller Katalanların tarafına geçmişler ve Bizans ordusunu yenilmesini sağlamıșlardır. Savaștan sonra Turkopoller Katalanlarla birlikte Trakya'daki yağma faaliyetine de katılmışlardır: Bkz. Öden, 1999, s. 26 çöktükten sonra Çanakkale'nin doğusundaki kentlere akınlar yapan Demir Han'la müzakere etmeye niyetlenmişti. Demirhan Bey büyük bir tevazu göstererek imparator Andronikos'la bulusstu. Daha sonra Demirhan Bey kendi ordugâhına, Andronikos da Biga'ya dönmüştür. Demirhan Bey ertesi gün yeniden Doğu Roma imparatoruyla görüşerek onu selamladı ve bundan sonra hiçbir Bizans şehrine saldırmayacağını söyledi. Demirhan Bey bu sözünü tutmuş ve Bizans topraklarına bundan sonra hiç saldırmamıştır. (Öden, 1999, s. 47)

\section{1) Yahşi Bey'in Deniz Seferleri}

İbn Battuta ve El-Ömeri5 gibi çağdaş kroniklerin naklettiklerine göre Karesi Beyliği'nde Bergama merkezli Yahşi Bey ve Balıkesir merkezli Demirhan Bey olmak üzere ikili bir yönetim bulunuyordu. El-Ömeri Yahşi Bey'in 20 bin süvarisi ve denizde hazır gemilerinin var olduğunu da söylemiş, Demirhan Bey'in askeri kuvvetine değinmemiştir. (İbn Battuta, s. 295; El-Ömeri, s. 165-166) Karesi Bey'in vefatından sonra yönetimi devralan Yahşi Bey, dönemin konjonktürel koşulları gereğince beyliğin merkezini Bergama'ya tașımıștır. (Öden, 1999, s. 35) Yahşi Bey’in dönemi Karesi Beyliği'nin en parlak zamanı olarak belirtilir. Demirhan Bey'in Bizans'la yaptığı ateşkesten dolayı bütün askeri faaliyetlerin Yahşi Bey tarafından yapıldığı anlaşılmaktadır. Yahşi Bey 1329 yılında yetmiş parçalı donanma inşa ettirdikten sonra Gelibolu'ya akınlar düzenlemiş, Çanakkale Boğazı'nda üstünlük mücadelesi vermiştir. (Bayar, 2019, s. 44) Yahşi Bey aynı zamanda Enez civarına ve Beres tarafina gemilerle çkarma yaparak Trakya üzerine akınlar da bulunmuştur. Bitinya'da Osmanlılara karşı mücadele etmekte olan III. Andronikos'a 1330'da Karesililerin Cisson, Polybotum, Aconiten ve Rodoscuk'u tehdit ettikleri haberi ulaşmıs, Andronikos bu saldırıları püskürterek Türklerin bir kısmını esir almıştır. (Öden, 1999, s. 37)

\section{2) Edremit Deniz Savaşı (1334)}

Türklerin Batı Anadolu'yu istila etmeleri, yaptıkları akınlar Ege Denizi'nde pek çok kolonileri bulunan Venedik'in tepkisini çekmiş, Güney Ege'de Aydınoğlu Umur Bey'in tehlikeli bir ses haline gelmesi ve Kuzey Ege'de Karesili Yahşi Bey'in istikrarsız bir ortam yaratmas1 Türklere karş1 bir Haçlı ligi oluşturulmas1 kararının alınmasına yol açmıștır. (Çavuşdere, 2016, s. 199, 202) Aslinda Avignon Papasi XXII. Iohannes'in 1316 'da göreve gelmesinden itibaren Katolik güçleri Türklere karş1 girişimlerde bulunmaktaydılar. Venedikliler Türk aleyhtarı bir siyaset izlemeye 1320'lerin ortalarında başlayarak, konunun Papalık curia'sında tartışılmasını sağlamışlardı. Bu aynı zamanda Venediklerin Doğu Roma'ya karşı daha olumlu bir tavrı benimsemesine yol açtı. Venedik kayıtlarında Türk korsanlarının 1321'den itibaren faaliyetleri ve

5 El-Ömeri tam adıyla Şihabeddin el-Ömeri XIV. Yüzyıl Memluk müverrihidir. "Mesâlikü'l-ebsâr" adlı eseri Anadolu Beylikleri hakkında bilgiler vermiștir. Diğer bir müverrih olan Kalkașendi de Anadolu Beyliklerinden bahsederken El-Ömeri'den faydalanmıstır: Bkz. Öden, 1999, XVII; İbn Battuta Merini hanedanının yönettiği Fas Sultanlığı'ndan Ebu İnan'ın isteği üzerine "Tuhfetü'l-nuzzar fi gara'ib el-emsâl ve acâib el-esfâr ya da kisaca Rihle (Seyahatname) adlı eserini İbn Cuzeyy'e yazdırmıştır: Bkz. Öden, 1999, XVI 
1325'te bu korsanlara karş1 bir tür "societas" ya da "unio"(birlik) kurulduğu geçmektedir. (Laiou, 1970, s. 379-380; Carr, 2015, s. 94-95) Anjou'lar, Papalik ve Venedik Batı Ege Denizi ile Yunanistan'da aynı ortak faydaya sahiplerdi. Buna rağmen Anjou'lar ve Papalık'ın ilk amac1 Anjou'ların Yunanistan'daki mülklerinde 6 Katalanlar ve Mistralılar gibi düşmanları ortadan kaldırmaktır. Bu konuda Anjou'ların Papalık desteğine dair izler Taranto prensi Filippo'nun 1320'lerin erken dönemlerinde Yunanistan'da bir ordu oluşturma girişimlerinde görülebilir. Nitekim Tarantolu Filippo'dan sonra Ahaya Prensliği gibi Yunanistan'daki Anjou mülklerini savunma işi kardeşi Gravinalı Giovanni'ye geçmiştir. Venedikliler ise Ege Adası'ndaki üslerinden dolayı Türklere karşı askeri bir harekât fikrindeydiler. (Carr, 2015, s. 94-95)

III. Andronikos Palaiologos'un 1328'de yeni İmparator olmas1 Venedik'in 1329-34 y1llarındaki yeni Doğu Akdeniz politikasını pekiştirmiş, Türklere karşı Doğu Roma ile işbirliği arayışına girilmiştir. (Laiou, 1970, s. 383-384; İnalc1k, 1993, s. 314) 1329'da Türklere karş1 ittifak kurma planları hala vasat düzeydeydi. Venedik Eğriboz'dan ve Thebes'nin baspiskoposundan temsilcileri alırken, basspiskopos batıda Venedik'e ve Papalık curia'sına gelip Venedik mülklerindeki yoğun Türk tehdidinden bahsediyor, savaş ilan edilip sefer kararı alınması dişında yeni bir şey söylenmiyordu. (Laiou, 1970, s. 383-384) Venedik ve imparator III. Andronikos arasında yerel çapta bir işbirliği oluşturulmuştu. Her iki taraf da Akdeniz'deki Cenova gücünü azaltmak ve Türk korsanlarının faaliyetlerine son vermekle ilgilenmekteydi. Doğu ve Batı kiliseleri hakkında yapılan olumsuz müzakereler nedeniyle Papa XXII. Iohannes Doğu Roma'ya mesafeli bir tutum sergilerken Venediklileri de Katalan aleyhtarı olmadıkları için eleştiriyordu. Aynı sene 1329'da Marino Sanudo Torsello Napoli Krallığı kançılaryasına ve Papanın yeğeni Petro de Via'ya Ege Denizi'ne yapılan pek çok Türk akınlarından bahsedip bu bölgelerde yaşayanların yardıma ihtiyaçları olduğuna değinmişti. (Laiou, 1970, s. 384; Carr, 2015, s. 96-97) Sanudo Papalık legate'1 ve Ostia piskoposu Bertrand'a da mektup yazarak Romania ve Ege Adaları'nda Türklerin akınlarından ve pek çok Hristiyan genci esir almalarından bahsetmiştir. (Laiou, 1970, s. 384) 1330 yılından itibaren Türklere karşı Haçlı Ligi kurulması planlarına resmen başlandı. Venedik senatosu 1331'de Stato da Mar'a (Venedik Cumhuriyeti'nin denizde yer alan topraklarına verilen isim kalıbı) bağlı güçler olan Negroponte (Eğriboz) bailo'larına, Girit düküne Türklere karş1 birleşme emrini verdi. (Carr, 2015, s. 70) Papa Iohannes'in esas arzusu Kudüs'ü geri almaktı. Fransa kralı VI. Philippe de Valois da bu fikri destekliyordu. Venedikliler Ocak 1332'de Avignon ve Fransa'ya elçi göndermişler, Türklere karşı Haçlı ligi kurulması için onları ikna etmeye çalışmışlardır. Fransa kralı ile 17 Aralık 1331 tarihinden itibaren başlayan ve 11 Mayıs 1332'de devam eden mektuplassmalarda ise Venedikliler Kudüs'ün kurtarılması için 50 bin piyade ve 20 bin atlının yeterli olacağını, böyle bir sefer için Memluk limanlarının abluka altına alınması ve Ege Denizi'nde

\footnotetext{
6 Napoli Krallığı'nı yöneten Anjou'lar 14. Yüzyılın ilk zamanlarında aslında bir Frank Prensliği olan Ahaya Prensliği'nde ve onun bağımlılıklarında egemenlik kurdular. Gravinalı Giovanni ve Taranto prensi Filippo, Mistralı Yunanlara ve Atina Dukalığı'nı ele geçiren Katalanlara karşı Ahaya
}

Türklerin durdurulması gerektiğini belirttiler. Venedikliler bu görüşlerini, Haçlı ikmali için elzem olan ve Karadeniz'den gelen tahıl ulaşımının Türkler tarafından engellendiği yönünde iddialarıyla kuvvetlendirmişlerdi. (Laiou, 1970, s. 385; Carr, 2015, s. 97-99; Setton, 1976, s. 178-9) Bir ay önce Venedikliler Napoli kralı Bilge Robert'e (Roberto il Saggio) de mektup yazarak aynı çağrılarda bulundular. (Laiou, 1970, s. 385) Papalık ve Fransa Kralı Philippe Venediklilerin görüşlerine katılıp artık ikna olduktan sonra Papa Iohannes diğer Hristiyan ülkelerini oluşturulacak bu Haçlı ligine davet etti. Doğu Roma temsilcileriyle kiliselerin birliği için müzakereler yeniden başlatıldı. Çünkü o dönemin Hristiyan âleminde Kudüs'ün kurtarılmasının Katolik ve Ortodoks kiliselerinin birleşmesiyle mümkün olabileceği inancı vardı. (Carr, 2015, s. 97-99)

Venedikliler de Türk korkusu o kadar fazlaydı ki 22 Haziran 1332'de Venedik senatosu, kâfirlerle ticaretin onlara güç katacağı nedeniyle, Türklerle ticaret yapan Venedik tüccarlarına ağır cezalar getirmişti. (Setton, 1976, s. 180) 7 Temmuz'da Venedik doge'u Francesco Dandolo Girit ve Eğriboz lordlarına Naksos dükü Niccolo Sanudo, Tenos ve Mikonos lordu II. Bartolomeo Ghisi ve Hospitalyelerle birleşmeleri, Türklere karşı savaşmaları için mektup yazd1. (Carr, 2015, s. 70; Laiou, 1970, s. 386; Setton, 1976, s. 180) Eğriboz bailo'su Pietro Zeno ve Venedik'in Adriyatik Körfezi kaptanı Petro de Canale, Doğu Roma imparatoru III. Andronikos ile birlik kurmak için, temsilci olarak tam yetkiyle gitmişler, Andronikos da onları 26 Ağustos 1332'de kabul ederek ittifaka katılmıştır. Canale aynı zamanda Venedik ve Doğu Roma adına Hospitalye şövalyeleri büyük ustası Helion de Villeneuve ile 6 Eylül 1332 yilında Rodos'ta görüşmüş, böylece tarihlere 1332 Haçli Ligi olarak geçen "Haçl1 Ligi" resmen kurulmuştur. Görüşmelerde kurulan Haçlı ligi için donanmanın miktarı da belirlenmiştir. 20 kadirgadan oluşacak donanmada Doğu Roma 10, Venedik 6, Hospitalye 4 kadırga temin edecek, donanma 15 Nisan 1333'te Egrriboz'da toplanacaktır. Canale ve Villeneuve donanma komutanının, Papa itiraz etmediği sürece, Venedikli olması gerektiği hususunda da anlaşmışlardır. (Carr, 2015, s. 70-71; Setton, 1976, s. 180; Laiou, 1970, s. 386) Birliğin amacı "ad persecutionem Turchorum et defensionem fidei ortodoxe: Türkleri bozguna uğratmak ve gerçek dini savunmak" diye tanımlanmıştır. (Setton, 1976, s. 180; Nicol, 2000, s. 241-242) Belirlenen tarihte 1333 yazında Girit'te isyan çıkması, Aydınoğlu Umur Bey'in Modon, Koron ve Eğriboz'a akınlar yapması nedeniyle harekete geçilmemişti. (Carr, 2015, s. 72; Nicol, 2000, s. 242)

Bu süre zarfında Kıbrıs Krallığ1 ve Fransa'nın desteği sağlanmış, Venedik ve Hospitalye elçileri Papalık curia'sıly görüşmüştür. 2 Ekim 1333 tarihinde Paris'te Haçlı seferi duyurulmuş, geleceğin papası Rouen basspiskoposu Pierre Roger "VI. Clement" kendilerini kutsal topraklarda Haçlı yolculuğuna katılmaya adayan Burgonya, Bourbon, Brabant dükleri ile Navarralı III. Philippe gibi Fransız soylularının meclisinin önünde

Prensliği'ni savunuyorlard1. Filippo'nun onlara karşı 1312 yılında iki bin şövalye ve dört bin piyadeden müteşekkil kuvvetle saldırı planı gerçekleşmedi. Gravinalı Giovanni'nin 1325 yılındaki masraflı seferi de başarısızlıkla sonuçlandı: Bkz. Housely, 1981, s. 548-556 
vaazlar vermiştir. Kasım 1333'te Fransa kralı VI. Philippe Haçlı ligine destek sözü vermiş ve 12 Kasım 1333'te Haçlı liginin harekete geçeceği tarih Mayıs 1334 diye belirlenmiştir. (Setton, 1976, s. 180; Laiou, 1970, s. 387; Carr, 2015, s. 72) Papalık curia'sında görüşmeler sonucunda katılımcilar 1334 yilının ilk aylarında 40 kadırgadan müteşekkil bir donanma oluşturmaya karar vermişlerdir. Bunların 10'u Venedik, 10'u Hospitalye, 6'sı Doğu Roma, 6'sı Kıbrıs ve 8'i Papalık-Fransa birleşiminden teşekkül edecektir. (Carr, 2015, s. 72) Napoli kralı Bilge Robert Ocak 1334'te bu lige destek olarak 16 adet gemi hazırlatma emri vermişti. Buna rağmen İtalya'da devam Guelf-Ghibellin Savaşları ile Sicilya Krallığı'na karşı yapılan savaşlar onu doğudaki Haçlı ligiyle ilgilenmekten alıkoymuştur. (Housely, 1981, s. 548-556) Venedik Doge'u Francesco Dandolo'ya 8 Mart 1334'te mektup gönderen Papa XXII. Iohannes Papalık-Fransa gemilerinin amirali olarak Jean de Cepoy'u (Cepoylu Jean) atamıștır. (Carr, 2015, s. 99; Thomas ve Predelli, 1880, s. 244-245) Papalik, Venedik, Hospitalye Şövalyeleri, Kıbrıs Krallığı ve Fransa Krallığı'nın teşkil ettiği, amiral Pietro Zeno komutasındaki, birlessik Haçlı donanması Ege Denizi'ne ulaştıktan sonra Edremit Körfezi'ne gelerek Yahşi Bey'e meydan okumuşlardır. Doğu Roma imparatoru III. Andronikos desteğini çok geç bir zamanda gönderdiğinden ittifak kuvvetlerine yetişememiştir. Karesi donanması Haçlı donanmasının geri çekilmesini beklemesine rağmen daha sonra savaşı kabul etmiştir. 17 Eylül 1334 tarihinde yapılan Edremit Deniz Savaşı'nda Yahşi Bey Haçlılar tarafından mağlup edilmiş, Karesi donanmas1 250 gemisini kaybederek imha olmuş, Yahşi Bey'in damadının da bulunduğu 3000'e yakın asker şehit düşmüştür. (Çavuşdere, 2017, s. 106; Öden, 1999, s. 40-41; Housely, 1981, s. 548) Buna rağmen Sanudo Kibrıs kralı IV. Hugh'e mektubunda taraflar arasinda Kutsal Bakire Meryem Bayramı'na denk gelen 8 Eylül'de ve 14 ile 17 Eylül gibi farklı tarihlerde tartışmalı biçimde çatışma yaşandığını belirtmiştir. (Carr, 2015, s. 73) Savaş hakkında yazan diğer önemli bir araştırmacı V. Laurent ise Edremit Deniz Savaşı'nın 17 Eylül 1334 ile Kasım 1334'te iki aşamalı gerçekleştiğini söylemiştir. (Laiou, 1970, s. 387)

Savaşın yapıldığı Edremit Körfezi Karesi donanmasının merkeziydi. Gemiler düz bir sahil şeridindeki kıyılara çekilmek için inşa edilmekteydiler. (Bayar, 2019, s. 47) Donanmanın savaşçı unsurları Türk, gemi ustaları ise yerli unsurlardan oluşmaktaydı. Ayrıca inşa edilen gemi türleri Doğu Roma tekniklerine dayalı küçük kadırga veya "dromon" tiplidir. (Bayar, 2019, s. 47-48) Ünlü İtalyan kronik yazarı Giovanni Villani de "Come $i$ Turchi furono sconfitti in mare da galee de la Chiesa e del re di Francia: Türkler Papalık ve Fransa kadırgaları tarafından denizde nasıl mağlup edildiler" başlığıyla Edremit Deniz Savaşı hakkında bilgiler vermiştir. (Villani, s. 1242) Onun verdiği bilgilere göre 32 kadırgadan oluşan Haçlı donanması Türklere karş1 savunma amaçlı Yunanistan'a gönderilmişti. Savaş sonucu Türkler beş binden fazla kișiyi kaybettiler ve yüz elli parçalı donanmaları yakıldı. (Villani, s. 1242) Batılı kaynaklar Edremit Deniz Savaşı'nın yapıldığı yer olarak Edremit Körfezi yerine hatalı biçimde Yunanistan'daki Teselya Yarımadası ve sahillerini, buralardaki Demetrios ya da Volos'u belirterek abart1lı destansı bir hava katma eğilimi göstermişlerdir. (Öden, 1999, s. 41)
Haçlılar Edremit Deniz Savaşı'nda aldıkları galibiyetle dönemin kaynaklarının belirttiği gibi çok önemli bir başarı elde etmişler, Akdeniz ve Ege Denizi Katolik âlemi için daha önce görülmeyen biçimde güvenlikli hale gelmiştir. Ayrıca Hospitalye, Venedik ve Kıbrıs güçleri birleştikleri durumda Türk saldırılarına karşı koyabileceklerini göstermişlerdir. (Carr, 2015, s. 73-74) Edremit Deniz Savașı'nın ardından sonbaharın son döneminde Haçlı donanması Avrupa'ya dönmüştür. (Laiou, 1970, s. 388) XXII. Iohannes doğuda Kilikya Ermeni Krallığı'na yardım sağlamak ve Türklere karşı mücadele etmek amacıyla yeni bir Haçlı ligi daha oluşturma peşindeydi. Napoli Kralı Bilge Robert'ten sefer için destek istemişti. Oluşturulacak bu güce 400'ü Papalık ve Fransa, 200'ü Hospitalye, 100'ü Kıbrıs kralı IV. Hugh ve Bizans imparatoru olmak üzere 800 kişi katılacak, Venedik ve Napoli'den kadırgalar temin edilecekti. (Carr, 2018, s. 219) Fransa kralının kuzeni Clermontlu Louis bu seferin kumandasina tayin edilse de Ekim 1334'te hem Nimes ve Beaucaire seneschal'i hem de kraliyet danışmanı olan Hugh Quieret onun yerini ald1. XXII. Iohannes'in ardindan 8 Ocak 1335'te papa seçilen XII. Benedikt ilk döneminde daha önceki bütün Haçlı teşebbüslerine destek vermiştir. Benedikt Napoli Kralı Robert'e önceki papa Iohannes'in yaptığ çağriyı yinelemişti. Yine bu amaçla Avignon'da bulunan Fransa, Hospitalye ve Venedik temsilcileriyle yeni Haçlı seferi hazırlıklarını hızlandırmak için buluşmuş, yeni Papalık kaptanı Hugh Quieret'e enduljanslar ihsan edip sefere desteğini belirtmek amaciyla Marsilya'da 4 papalık kadırgası inşası emrini vermişti. (Carr, 2018, s. 219-220) Bu kadırgalara Fransa'dan 5 parça daha eşlik edip Mayıs'ta yola çıkacaklar ve Ege Denizi'nde beş ay süreyle hizmet edeceklerdi. Benedikt aynı zamanda Fransa kralı VI. Philippe'in Kudüs'e yapacağı seferi, önceki Haçlı seferi fermanlarını onaylayarak desteklemiştir. (Carr, 2015, s. 100-102) Buna rağmen Fransa Krallığı ve İngiltere arasinda Yüz Y1l Savaşları'nın başlaması bütün planları değiştirmiş, Fransa krallığı Haçlı seferi için sağladığı donanmayı 1336'da İngiliz Kanalı'na göndermek zorunda kalmıştır. (Carr, 2015, s. 100-102) Avrupa'daki finansal kurumlar1 etkileyen zorluklar kutsal topraklara yapılması hedeflenen seferi zorlaştıran diğer bir etken olmuştur. $\mathrm{Bu}$ nedenlerden dolayı XII. Benedikt Fransa kralına yazdığı mektupta Haçlı seferi planlarının iptal edildiğini belirtmiş, 13 Mart 1336'da Benedikt Fransa kralından Avrupa devletleri arasinda durum sakinleşene kadar Haçlı planlarını askıya almasını rica etmiştir. (Setton, 1976, s. 180; Carr, 2015, s. 100-102)

Yahşi Bey Edremit Körfezi'nde aldığı ağır yenilgiden dolay1 uzun bir mühlet akınlarda bulunmayıp sahillerden çekilmiştir. Yine de Nikeforos Gregoras'in naklettiğine göre 1337'de Trakya'ya Karesi akınları gerçekleşmişti. (Öden, 1999, s. 43-44) 1341-42 yıllarında yeniden akınlara başlayan Yahşi Bey Bergama'dan Gelibolu Yarımadası'na yönelik saldırılara başlamış, ona bu saldırılarında Saruhanlılar da destek vermiştir. V. Ioannes Palaiologos'a karşı taht mücadelesi (1341-46) veren Ioannes Kantakuzenos Karesi ve Saruhan saldırılarını savunması için Apokaukos isimli komutanını görevlendirmişti. (Öden, 1999, s. 43-44) Fakat bu saldirılar devam edince Kantakuzenos bizzat Gelibolu'ya gelmeye mecbur kald1. Doğu Roma kuvvetleri Gelibolu'da Yahşi Bey'e ait kuvvetleri iki defa üst üste yenmişler ve Karesilileri barış yapmaya itmişlerdi. Yahşi Bey 1341 yılındaki bu barışla tüm 
deniz seferlerine nokta koyup Doğu Roma'ya bir daha saldırmayacağına yemin etmiştir. (Öden, 1999, s. 43-44) Yahşi Bey'in vefatından sonra Demirhan Bey'in kardessi ya da oğlu olduğu tartışma konusu olan Süleyman Bey başa geçmiştir.

\section{SONUÇ}

14. yüzyılın ilk çeyreğinde başlayan ve 1330-40 arasında zirve noktasını yaşayan Türk denizcilerinin akınları tüm Hristiyan âlemini siyasi ve sosyo-ekonomik açıdan etkilemiştir. Onların Ege Denizi'ndeki faaliyetleri ticaret noktalarına sahip İtalyan kent devletlerine özellikle Venediklilere zarar vermiştir. Venedikliler 1320'lerden itibaren Papalık dâhil Avrupa'daki Hristiyan güçlere Türklere karşı bir ittifak ligi oluşturulması için çağrılar yapmıștır. Papa XXII. Iohannes ve Fransa kralı VI. Philippe'in ise esas amaçları Kudüs'ü Müslümanlardan alıp Hristiyanlara geri kazandırmaktı. Hem Karesili Yahşi Bey ve Aydınoğlu Umur Bey'in gaza faaliyetleri hem de Sanudo gibi Venedikli önde gelenlerin propagandaları, Papalık ve Fransa'yı Türklere karşı bir Lig oluşturmaya itti. Aynı esnada Batı Anadolu'dan gelen Türk saldırılarına maruz kalan Doğu Roma imparatoru III. Andronikos ve Türklerle 1310'lardan itibaren savaşan Hospitalye Şövalyeleri de Venediklilerin yanında bu ittifaka katılmışlardır.

Edremit Deniz Savaş1 1291'de Akka'nın düşmesinden sonra Haçlıların ilk önemli başarısı olmuştur. Savaşın sonucunda Türk denizcilerinin akınları bir nebze de olsa azalmış, bölgedeki Hristiyan gemileri rahatça seyrüsefer yapabilmişlerdir. Buna rağmen Edremit Deniz Savaşı'ndan sonra Aydınoğlu Umur Bey ve kuvvetlerinin Ege Denizi'nde yoğun biçimde faaliyet göstermeleri bölgedeki Hristiyan gemilerinin güvenliğini yeniden tehlikeye sokmuş ve Katolik güçlerini tekrar Türklere karşı ittifaka itmiştir. Edremit Deniz Savaşı'ndan sonra Fransa tarafından Kudüs'e düzenlenmesi hedeflenen Haçlı seferi 1337'de başlayan Yüz Yıl Savaşları (13371453) ve ekonomik zorluklar nedeniyle Papa XII. Benedikt tarafından askıya alınmak zorunda kalınmıştır. Edremit Deniz Savaşı'nı kazanan Haçlı Ligi gelecekteki Haçlı Liglerine örgütlenme, istihbarat ve dayanışma açısından örnek olmuştur. Edremit Deniz Savaşı'nın diğer bir sonucu Avrupa'da 1396'da Niğbolu ve 1444 'te yapilan Varna Savaşlarına kadar tamamen Türkleri hedef alan Haçlı seferleri geleneği doğurmasıdır. Batı Anadolu Beylikleri ve Osmanlılar bu haçlı seferleri geleneği karşısında İslam âleminin tehlikede olduğunu düşünerek savunma mekanizması geliştirmişler ve gaza olgusuna sarılmak zorunda kalmışlardır.

\section{KAYNAKÇA}

Bayar, U. (2019). Türkiye Selçuklu ve Beylikler Dönemi Batı Anadolu'da Türk Denizcilik Faaliyetleri. (Basılmamış Yüksek Lisans Tezi). Gazi Üniversitesi/Sosyal Bilimler Enstitüsü, Ankara.

Carr, M. (2015). "Latin Response to the Turks: The Naval Leagues". Merchant Crusaders in the Aegean, 12911352. Woodbridge: Boydell \& Brewer, Boydell Press, s. 63-78.

Carr, M. (2015). "The Papacy and the Naval Leagues". Merchant Crusaders in the Aegean, 1291-1352. Woodbridge: Boydell \& Brewer, Boydell Press, s. 94-118.

Carr, M. (2018). "Benedict XII and the Crusades". Pope Benedict XII (1334-1342). Amsterdam: Amsterdam University Press, s. 217-240.

Çavuşdere, S. (2016). Avrupa'nın Türk Sorunu. İstanbul: Yeditepe Yayınları.

Çavuşdere, S. (2017). Orta Çağ'da Venedik, Papalık ve Türkler. İstanbul: Yeditepe Yayınları

Ebu Abdullah Muhammed İbn Battuta Tanci, (2018). İbn Battuta Seyahatnamesi. (Sekizinci Baskı). (Çev. A. Sait Aykut). İstanbul: YKY.

Housely, N. J. (1981). Angevin Naples and the Defence of the Latin East: Robert the Wise and the Naval League of 1334, Peeters Publishers, Byzantion, Vol. 51 , No. 2, s.548-556.

Inalc1k, H. (1993). The Rise of the Turcoman Maritime in Anatolia, Byzantium and the Crusades. Indiana Universty Turkish Studies and Turkish Ministry of Culture Joint Series Vol. 9. Bloomington: 309-329.

Laiou, A. (1970) Marino Sanudo Torsello, Byzantium and the Turks: The Background to the AntiTurkish League of 1332-1334. Speculum 45 (3), s.374-392.

Miller, W. (1908). The Latin in The Levant, New York: E. P. Dutton and Company.

Nicol, D. M. (2000). Bizans ve Venedik Diplomatik ve Kültürel İlişkiler Üzerine, (Çev. Gül Çağalı Güven), İstanbul: Sabancı Üniversitesi Yayınları.

Nicol, D. N. (2016). Bizans'ın Son Yüzyıllar 1261-1453. (Çev. B. Umar). İstanbul: TỉBK Yayınları.

Ostrogorsky, G. (2015). Bizans Devleti Tarihi. (Sekizinci Bask1). (Çev. Fikret Iş1ltan).

Ankara: TTK Yayınları.

Öden, Z. G. (1999). Karası Beyliği. Ankara: TTK Yayınlar1.

Raffaele, D' Amato, (2016). Byzantine Naval Forces (1261-1461). (Illustrated; P. Dennis, I. Dzis). New York: Osprey Publishing.

Setton, K. M. (1976). The Papacy and the Levant (12041571), Volume I, Philadelphia: The American Philosophical Society. 
Şihabeddin b. Fazlullah El-Ömeri, (2014). Türkler Hakkında Gördüklerim ve Duyduklarım (Mesaliku'1 Ebsar), (Çev. D. Ahsen Batur). İstanbul: Selenge Yayınları.

Thomas, G. M. ve Predelli, R. (Ed.). (1880). Diplomatarium Veneto-Levantinum: sive, Acta et diplomata res venetas, graecas atque levantis illustrantia. Pars I: a. 1300-1350. Venetiis: Sumptibus Societatis.

Turgut, V. (2016). "Karası Beyliği”. H. Şahin (Editörler). Anadolu Beylikleri El Kitabı.

İstanbul: Grafiker Yayınları.

Uzunçarş1l, İ. H. (2003). Anadolu Beylikleri ve Akkoyunlu, Karakoyunlu Devletleri, (5. Bask1). Ankara: TTK Yayınları.

Vasiliev, A. A. (2016). Bizans İmparatorluğu Tarihi. (Çev. Tevabil Alkaç). İstanbul: Alfa Yayınları.

Villani, G. (1991). Nuova Cronica, a cura di G. Porta, Parma: Fondazione Pietro Bembo/Guanda.

Zachariadou, E. (1983). Trade and Crusade: Venetian Crete and the Emirates of Menteshe and Aydin (1300-1415). Venice: Istituto Ellenico di Studi Bizantini e Postbizantini di Venezia per Tutti i Paesi del Mondo. 